\title{
Research on Evaluation Mechanism of Teaching Management of Military Professional Degree Postgraduate Education
}

\author{
Jie Luo ${ }^{a, *}$, Yanhao Zeng ${ }^{b}$ \\ Complete Projiect Research, Logistics University of Chinese People’s Armed Police Force, Tianjin, China \\ a502335602@qq.com, b1240133927@qq.com
}

Keywords: Evaluation Mechanism of Graduate Teaching Management, Index System of Teaching Management Evaluation, The Application of the Evaluation of Teaching Management of Postgraduates in Military.

\begin{abstract}
It is an essential guarantee to improve the quality of teaching by cultivating high-end comprehensive application talents for the army and the evaluation mechanism of teaching management. It is an indispensable role for the comprehensive strength of the institutions. It is an important part of the management of the postgraduate education. The evaluation of the management activities of the major links in the whole process of postgraduate education has a certain supervision, feedback and promotion role in the teaching management work. On the basis of discussing the main contents and design basis of postgraduate education management evaluation of military professional degree, this paper constructs a series of indicators to reflect the teaching management level of postgraduate education of professional degree, and makes a prospect for the follow - up work of evaluation.
\end{abstract}

\section{Introduction}

This paper mainly evaluates the teaching quality of graduate degree education by means of teaching management evaluation indirectly. At present, there are obvious shortcomings in the teaching management evaluation of the military professional degree. There are three obvious points in the evaluation of teaching management: First, the degree of emphasis on the evaluation of teaching management is not high enough for the professional degree graduate education; The second is that the concept of the evaluation of the teaching management of the postgraduate education Is lagging behind; The third is the professional degree graduate education teaching management assessment team construction is still in the primary level stage [1]. Through the assessment of all the management work involved in the whole process of the postgraduate education of the military professional degree, it is necessary to understand the management level and the running ability of the postgraduate education of the military professional degree to a certain extent. The comparative evaluation finds that the current educational management of the military professional degree exists problems and shortcomings, pointing out that teaching management of military professional degree postgraduate education can improve the direction. By this way, it can improve the level of education and teaching quality that provide some guidance and related supporting measures to Eguide the teaching management of the overall development and progress. Gradually, All things can to the normal, scientific, standardized, institutionalized.

\section{The Design Mechanism of Teaching Management of Military Professional Degree Postgraduate Education}

\subsection{The Design Content of Teaching Management Evaluation}

Teaching management assessment is a comprehensive assessment of the whole process of teaching management, the main contents are: vertical, including basic management, program management, business management and feature management; horizontal mainly including organizational management, related systems Management, professional construction management, 
teacher power management, teaching equipment management, teaching-book system management, planning document management, examination situation management, graduation thesis management, basic condition management, information network management, information construction management, teaching operation management, teaching quality management, teaching construction management, satisfaction level management, innovation mechanism management, etc.

\subsection{The Purpose of Teaching Management Evaluation}

The purpose of the teaching management assessment is to conduct a comprehensive scientific "detection and assessment" of the human, material and financial resources related to the teaching management work. According to the "standards and norms" of the teaching management, it can evaluate the level and effect of teaching management and inform the corresponding evaluation of diagnosis and improvement, so that teaching management activities can run more smoothly, to ensure the successful completion of teaching objectives.

\subsection{The Design Steps of Teaching Management Assessment}

The most important part of the design step of teaching management assessment is to build an independent, authoritative and diverse assessment team. The evaluation of the teaching management of postgraduates in the military is not only the work of the teaching management departments of the institutions, but the units or individuals associated with the teaching management can participate. It can be considered from the various schools dispatched teachers experts to form a temporary teaching management assessment team, from different angles on the college teaching management work evaluation. On the one hand, it's conducive to promoting the overall management of the school efficiency jump, and then can improve the teaching quality and level of the military professional postgraduate education; On the other hand, you can take the opportunity to ask these experts and scholars to compare the horizontal comparison of the current teaching management to find the gap and scientific improvements.

\section{The Index System of Teaching Management Evaluation of Postgraduates in Military}

\subsection{Design Criteria for Teaching Management Evaluation Index System}

The design standard of the index system has laid the foundation for the design evaluation index, which is the basic criterion for confirming the index. The design standard of the evaluation index can clarify the relevant basic points of the index design and lay down solid foundation for the standard of the design of the index system. The design criteria of the index system are beneficial to the "effectiveness and scientific nature" of the teaching management activities and to make every effort to reduce the possible "one-sidedness and side effects".

\subsection{Design Principles of Teaching Management Evaluation Index System}

The construction of the evaluation system of postgraduate teaching management of military professional degree should follow the principle of comprehensiveness, objectivity, goal orientation, feasibility of method and comparability of result.

\subsubsection{The Principle of Comprehensiveness}

It can use the systematic thinking, involving the teaching management of all the activities of the full assessment in order to reveal the nature of teaching management and obtain a complete and comprehensive, scientific and accurate assessment of teaching management system [5]. In addition, while insisting on comprehensiveness, we should ensure that the same level of indicators are not included in each other, not contradictory, so independent of each other.

\subsubsection{The Principle of Objectivity}

The design of $\mathrm{T}$ the contents of teaching management evaluation should reach to maximize the objective, quantify the quantification. For something not easy to quantify the need, we should make it the greatest possible clear and unambiguous, and can't take it ambiguous, so as not to leave the 
subjective assumptions to the subject opportunities that affect the objective accuracy of the results of the assessment.

\subsubsection{The Principle of Goal Orientation}

Indicators should clearly show the military on the " the positioning of institutions ", that is to cultivate the ability to adapt to the actual needs of the "application of talent." In the design of teaching management evaluation indicators, it should be conveyed a clear guiding information, to play its baton role, to guide the development of the next work plan

\subsubsection{The Principle of Feasibility of Method}

The feasibility of the index has two main requirements: Firstly, For the index system which can quantify, the relevant data must be collected to implement mathematical calculations and conduct the "quantitative processing"; Secondly, For the qualitative indicators which cannot quantify, it must be clearly and specific accurately described in order to scientifically and rationally make the corresponding "rating" and the second quantitative treatment.

\subsection{Design Content of Teaching Management Evaluation Index System}

Before designing the evaluation index system of teaching management, we should study the relevant instruction documents of the military academy, study the advanced teaching management evaluation indexes of foreign military colleges and universities, and combine the status quo of postgraduate education teaching management in our military. With reference to the Careersmart Balanced Score Card and other evaluation models, according to the relevant regulations within the army and the situation of the institutions, the author defines the evaluation scope of the postgraduate education and teaching management of the military professional degree as related to the whole process of all the management work of postgraduate education. It is a 360-degree all-round coverage assessment, around the whole school on the professional degree graduate education and teaching management of the basic requirements, to develop its teaching management evaluation index system. Specific indicators shown in Table 1: set the basic management, program management, business management, features management as four primary indicators. Here is a total of four the first indicator, a total of 16 secondary indicators, a total of 54 the third indicator.

Table 1 The Index System of Teaching Management Evaluation of Postgraduates in Military

\begin{tabular}{|c|c|c|}
\hline $\begin{array}{l}\text { The First } \\
\text { Indicators }\end{array}$ & $\begin{array}{l}\text { Secondary } \\
\text { Indicators }\end{array}$ & $\begin{array}{l}\text { The Third } \\
\text { Indicators }\end{array}$ \\
\hline \multirow{20}{*}{$\begin{array}{c}\text { Basic } \\
\text { Management }\end{array}$} & \multirow{3}{*}{$\begin{array}{l}\text { Organizational } \\
\text { Management }\end{array}$} & Management Structure \\
\hline & & Management Systems and Mechanisms \\
\hline & & Job Setting Management \\
\hline & \multirow{3}{*}{$\begin{array}{c}\text { Related Systems } \\
\text { Management }\end{array}$} & Management Business System \\
\hline & & Responsibility System Management \\
\hline & & Internal-control Management \\
\hline & \multirow{4}{*}{$\begin{array}{c}\text { Basic Condition } \\
\text { Management }\end{array}$} & Teaching Funds Management \\
\hline & & Life Service Management \\
\hline & & Good Environmental Management \\
\hline & & Infrastructure Management \\
\hline & \multirow{2}{*}{$\begin{array}{c}\text { Information } \\
\text { Network } \\
\text { Management }\end{array}$} & Teaching Information Network \\
\hline & & Teaching Information Processing \\
\hline & \multirow{4}{*}{$\begin{array}{c}\text { Teacher Power } \\
\text { Management }\end{array}$} & Teacher Structure Management \\
\hline & & Develop Planning \\
\hline & & Business Quality Assessment \\
\hline & & Teacher Training Management \\
\hline & \multirow{4}{*}{$\begin{array}{c}\text { Teaching } \\
\text { Equipment } \\
\text { Management }\end{array}$} & Teaching Equipment Management \\
\hline & & Laboratory Management \\
\hline & & Training Base Construction \\
\hline & & Online Learning Room Management \\
\hline
\end{tabular}




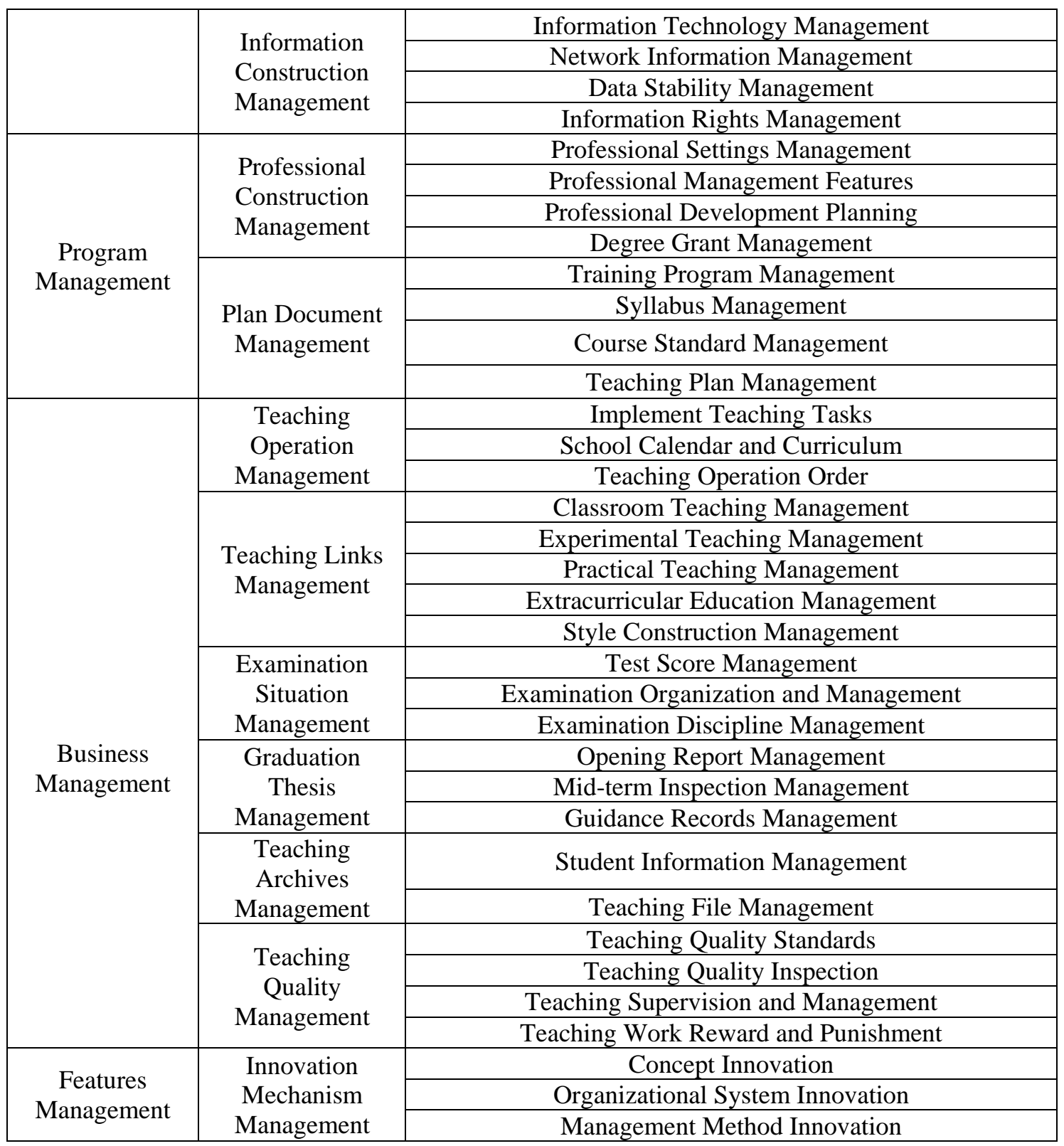

Respecting for indicators does not mean that only indicators are from, and we can set the mobility indicators. The evaluation index of the teaching management of military postgraduate education should not be immutable, but should form a dynamic and continuous development of the all-round index system. Only so many levels of the index system reflect can that the military professional postgraduate education and teaching management meet with development Law and the new period with a unique feature. The military academy in the teaching management assessment cannot copy each other, but according to the different characteristics and their respective development characteristics of different professional graduate students can make the appropriate choice and adjustment.

\subsection{Design Method of Weight Evaluation of Teaching Management Evaluation}

The determination of the weight of teaching management evaluation index directly affects the accuracy and validity of the evaluation results. How to allocate the index weight scientifically and rationally is an important part of the evaluation. At present, there are Delphi method, AHP (Rank Analysis), RSR (Rank-sum ratio), ANP (Network Analysis), Direct Judgment, Entropy Method, factor analysis method, three-dimensional determination method, correlation coefficient method, expert sorting method, arithmetic mean combination weighting method, gray clustering analysis method, fuzzy comprehensive evaluation method, continuous multiplication combined weighting method, importance sorting method, Mean square error method and principal component analysis 
method. Therefore, the military colleges and universities must flexibly use different evaluation methods according to their own characteristics.

\section{The Application of the Evaluation of Teaching Management of Postgraduates in Military}

\subsection{Post-evaluation of teaching management evaluation}

Feedback in the teaching management assessment refers to the timely and accurate feedback of the relevant issues identified in the whole process of teaching management assessment to the relevant organizational unit [7]. We can set up the corresponding "feedback team" to further enhance the "evaluation of the feedback" effect [8]. Mainly there are three forms of feedback: First, Real-time feedback runs through the assessment process. that is, during the assessment of the indicators, found that some common problems can be timely communication with relevant departments or personnel; Second, Using the comprehensive assessment report make full feedback. The relevant personnel must carefully read it, and find their own shortcomings; The third is to focus on feedback after completion of the assessment. The Interim Assessment Panel focused on constructive comments that were conducive to the overall development of the next step in teaching management.

\subsection{Development Prospect of Teaching Management Evaluation}

At this point the teaching management assessment work is a long time, but it is far from over. In the future institutions of graduate education management assessment should do the following two: On the hand, Assessment concept on teaching management should be updated. In order to make the teaching management evaluation really meet the objective law of the postgraduate education of the military professional degree and the long-term development demand of the army, we must always pay attention to the forefront of the teaching management evaluation concept, so as to timely update the teaching management evaluation team evaluation concept. On the other hand, Assessment method on teaching management should be flexible. Each evaluation should be based on different circumstances to choose a flexible combination of different methods, and combine the advantages of each method to avoid its lack of comprehensive and objective preparation to evaluate the military academy teaching management to lay a solid foundation.

\section{Chapter Summary}

This chapter constructs the evaluation mechanism of teaching management from the characteristics of postgraduate education and management of professional degree, and combines the risk management of project management, which can help to unveil the level of teaching management in colleges and universities, to promote the improvement of teaching quality, and to cultivate high-end applied talents for the army which is shortage. In the process of postgraduate education in the military professional degree, it is necessary to carry out the long-term evaluation mechanism to ensure the successful and efficient operation of teaching management. The shortcomings of this chapter is that the indicators are only three level indicators, there may be not enough specific circumstances, and also it cannot give the weight of the index and the corresponding specific scores. Hope in the next step to in-depth study.

\section{References}

[1] Wang Furong, Research on the dimensions of educational quality evaluation of the postgraduates with professional degree[D], Dalian University of Technology, 2011.

[2] Ying Zhao,Kai Zhou. How to Enhance the Teaching Quality of Independent College Assessment under the Credit System and Supervision[A]. Information Engineering Research Institute, USA. Proceedings of 2015 5th International Conference on Education and Sports Education(ESE 2015 V45)[C].Information Engineering Research Institute, USA:,2015:3. 